\title{
INSTITUTE OF REHABILITATION \\ IN THE NATIONAL LEGISLATION (1929-2011)
}

UDC 343.848

343.21(497.1)'”1929/2011',

\section{Tijana Stančevski*}

\author{
Faculty of Law, University of Niš, Serbia
}

\begin{abstract}
This year, it has been nine decades since the Criminal Code of the Kingdom of Serbs, Croats and Slovenes was put into effect on 29 January 1929. Apart from the unification of criminal laws on the entire territory of the Kingdom of SCS, where several different criminal laws had been in operation earlier, the new Code provided for the institute of rehabilitation unknown to the old criminal laws. In the aftermath of World War II, the Federal People's Republic of Yugoslavia (FPRY) was based on the tenets of the republican legal system. The new legal order introduced new criminal codes which were consistent with the times and the values that the new state was protecting: the 1947 Criminal Code of the FPRY, the 1951 Criminal Code of the FPRY, and the 1976 Criminal Code of the SFRY. All these Codes included provisions on rehabilitation. Nowadays, this institute is contained in the current Criminal Code of the Republic of Serbia and in special legislative acts on rehabilitation of political convicts of 2006 and 2011. This paper aims to examine the normative framework of rehabilitation in our legal system from the historical perspective.
\end{abstract}

Key words: rehabilitation, criminal laws, resocialization

\section{INTRODUCTION}

During his life, man encounters various challenges. Some people succumb to temptations, by causing harmful effects through their negative social actions. In that case, the state stands on the side of society and, through its appartus, imposes measures which should, on the one hand, affect the criminal offender and show him that his action is socially unacceptable or, on the other hand, indicate to the rest of society that the same type of sentence could be imposed on them should they commit the same or another punishable offense. The question is what happens to the convicted persons after serving the sentence. Do such persons have any rights?

Received November $20^{\text {th }}, 2019 /$ Accepted December $4^{\text {th }}, 2019$

Corresponding author: Tijana Stančevski, Faculty of Law, University of Niš, Trg Kralja Aleksandra 11, 18000 Niš, Serbia; E-mail: tijana.stancevski@gmail.com

${ }^{*} \mathrm{PhD}$ Student 
Do convicted persons become equal (in terms of rights) with persons who have never acted against the law, and when does this happen?

Modern criminal legislations support a standpoint that convicted persons should be enabled to resocialize after serving the sentence. Thus, a convicted person is fully integrated into the society, whereas the likelihood of re-offending is minimalized. Rehabilitation makes this possible. Etymologically, the word "rehabilitation" is derived from the Latin prefix "re" (again) and the adjective "habilis" (apt, fit, suitable, manageable). From the viewpoint of criminal law, rehabilitation is defined as restoring the social status of the convicted person whose criminal past is put behind and who is by law considered not to be convicted (Babić, Marković, 2015:451).

This paper examines the concept, characteristics, effects and the conditions for rehabilitation. The first part of the paper provides a historical overview and analysis of criminal law provisions on this matter in the period from 1929 to 1976. The second part of the paper analyzes the institute of rehabilitation in the current legislation of the Republic of Serbia, by exploring the provisions of the Serbian Criminal Code and the Criminal Procedure Code. The third part of the paper refers to the rehabilitation procedure envisaged in lex specialis.

\section{Historical DEVElopment of ReHABILITATION IN SERBia}

As an institute of criminal law, rehabilitation is one of the most significant rights that are conferred to convicted persons. In legal terms, this institute allows for the suspension of the pronounced or served sentence, and enables the convicted person to be considered as a non-convicted person (without prior convictions). On the one hand, the importance of the imposed sentence is reflected in the principle of both general and specific prevention. On the other hand, the purpose of punishment and serving the imposed sentence is to improve the conduct of the convicted person and enable resocialization of such a person after serving the sentence.

In the first part of the paper, the following laws will be observed in the context of the historical development of the institute of rehabilitation.

A) the Criminal Code of the Kingdom of Serbs, Croats and Slovenes of 1929

B) the Criminal Code of the Federal People's Republic of Yugoslavia-General Part of 1947

C) the Criminal Code of the Federal People's Republic of Yugoslavia of 1951

D) Criminal Law of the Socialist Federal Republic of Yugoslavia of 1976.

\subsection{Criminal Code of Serbs, Croats and Slovenes}

The Criminal Code of the Kingdom of Serbs, Croats and Slovenes ${ }^{1}$, adopted in 1929, signifies an important event in the history of our legislation. At that time, the contemporaries estimated that "the Criminal Code of Serbs, Croats and Slovenes is among the most modern criminal laws in Europe, based on more advanced ideas than those found in French, German or Italian codes" (Petrović, 1929: 114-118). Apart from "unifying the criminal laws in our state on whose territory several different criminal laws had been in operation" (Čubinski,

\footnotetext{
${ }^{1}$ Criminal Code of Serbs, Croats and Slovenes, Official Gazette of the Kingdom of Serbs, Croats and Slovenes, no. $33 / 1929$
} 
1934:3), an important feature of this law was the institute of rehabilitation which had existed in the former criminal legislation. It was considered that the essence of this institute "lies in the fact that the convicted person, who has been deprived of his civil (personal) and other rights provided by the law, is restored such rights. Amnesty can play the same role, but there is a significant difference because amnesty is an extraordinary measure used in exceptional cases, while rehabilitation is a regular measure" (Čubinski: 1934:21).

In the Criminal Code of Serbs, Croats and Slovenes, the institute of rehabilitation is defined in Chapter XI, under the title: "Restitution of Rights and Cancellation of Conviction (rehabilitation)". In terms of legal systematics, the institute of rehabilitation is regulated in a single article, which is divided into three paragraphs. Under Article 90 of this Code, rehabilitation implies that, after the expiry of the prescribed three-year time limit from the date when the imposed punishment has been served, abolished or outdated (under the statute of limitations), the court, acting upon the convicted offender's request, may proclaim the convict worthy of exercising and acquiring his lost rights, provided that the convict demonstrated proper conduct and, if possible, compensated the damage.

Article 46 of this Code provides that a permanent deprivation of civil (personal)_rights shall be imposed in cases involving a death sentence or a prison sentence exceeding 5 years (Čubinski, 1934: 167-168). This leads us to the conclusion that the restoration of civil rights is not allowed. In case the court imposed the prison sentence of up to five years, the offender could be deprived of civil rights for a period ranging from one to five years.

According to Article 47 of this Code, the loss of honorable rights was reflected in: 1) loss of the right to employment in civil or other public services; 2) loss of the right to the academic degrees, awards and other public honors, as well as political rights; and 3) loss of the right to vote and the right to be elected for a political function.

If the convicted person was deprived of civil rights for a period of time, after the expiry of that period, the lost rights would be restored and the person would be enabled to acquire other rights; namely, the person was allowed to perform a civil or other public function, as well as to attain academic degrees, awards and other public honors.

Article 90 (para.3) of this Code envisaged that, upon the expiry of five years after the sentence has been served, outdated or abolished, the court, acting upon a personal request of a person who was sentenced for the first time, may issue a decision annulling the imposed sentence together with all its legal consequences for a future period, provided that the convicted person was well-behaved while serving the sentence, and, that he compensated for the damage caused by the criminal offense. In this legal solution, we may observe the following mandatory requirements for granting rehabilitation: 1) that five years have elapsed upon the served, outdated or suspended sentence, 2) that the convicted person has filed a request for annulment of the sentence; and 3) that the person has been sentenced for the first time (first-time perpetrator), which further implies that it was not possible to ask for the erasure of conviction if the person was a recidivist.

As an optional condition for "annulment of conviction", the Code provides that the damage caused by a criminal offense should be compensated, if possible. However, although the the legislator allowed the possibility of voiding the legal consequences of conviction, the rights of third parties were not affected; therefore, regardless of the decision on annulment of the conviction, third parties were given an opportunity to claim compensation for damage. 


\subsection{Criminal Code of the Federal People's Republic of Yugoslavia- General part}

The 1947 Criminal Code of the Federal People's Republic of Yugoslavia (FPRY)General part ${ }^{2}$, in Chapter V titled: "Cancellation of the sentence" (Article 92), provides for the erasure of former convictions from records (rehabilitation). This Code distinguishes two types of rehabilitation: a) legal rehabilitation, and b) judicial rehabilitation.

Under this Code, an "unconvicted" person was defined as a person who: 1) was sentenced to correctional labor, imprisonment not exceeding six months, or a more lenient sentence, provided that he did not commit another criminal offense within three years from the date of the served or abolished sentence; or, 2) a person who was sentenced to a term of imprisonment ranging from six months up to three years, or imprisonment with forced labor for up to two years, provided that he did not commit another criminal offense within five years from the date of the served or abolished sentence. This provision refers to legal rehabilitation.

Another form of rehabilitation is judicial rehabilitation. It applies in cases when the person has been sentenced to the prison term of more than three years or a more stringent sentence, provided that after the expiry of the period of eight years from the date of the served or abolished sentence, the person files a request for erasure of conviction from records; the request may be approved under the following conditions: a) that the person was well-behaved all that time; b) that, by such conduct, he deserved to have his conviction erased; and c) that he compensated the damage caused by the committed criminal offence, if possible.

If the court adopts a decision to erase the conviction, such a decision can be annulled upon the request of the public prosecutor if the convicted person is established to have committed a criminal offense before the decision on erasure of conviction was issued, and if the court finds that, in such a case, there would be no grounds for rehabilitation of such perpetrator.

\subsection{Criminal Code of the Federal People's Republic of Yugoslavia}

The Criminal Code of the Federal People's Republic of Yugoslavia (FPRY) of $1951^{3}$ provided for the rehabilitation as well. This Code clearly distinguishes between legal and judicial rehabilitation; accordingly, in terms of legal systematics, each type of rehabilitation is regulated in a separate article.

Article 87 of this Code provides a general definition of rehabilitation. Thus, rehabilitation is intended to erase the conviction and terminate legal consequences, which ultimately results in the convicted person being considered to be "unconvicted" (without prior convictions). If the convicted person was imposed a secondary punishment in addition to the main one, by the decision on rehabilitation of the main sentence itself, all secondary sentences which had not been served would be cancelled. This Code also provided for the opportunity of third parties to seek compensation damage stemming from the conviction.

Pursuant to Article 88 of this Code, legal rehabilitation is granted only if the persons have not been convicted previously or if they could be considered under the law as unconvicted persons. The Code explicitly stipulates the following conditions for granting legal rehabilitation to: 1) the persons found guilty and released from sentence, provided

\footnotetext{
${ }^{2}$ Criminal Code of the FPRY-General part, Official Gazette of the FPRY, no 106/1947).

${ }^{3}$ Criminal Code of the Federal People's Republic of Yugoslavia, Official Gazette of FNRY, no. 13/1951.
} 
that they did not commit another criminal offense within a year from the final decision; 2) the persons sentenced to a fine or imprisonment not exceeding six months, provided that they did not commit another criminal offense within three years from the date when the sentence was served, outdated or abolished; and 3) those convicted to a term of imprisonment ranging from six months to two years, provided that they did not commit another criminal offense within five years from the date the sentence was served, outdated or abolished.

Under Article 89 of this Code, judicial rehabilitation is allowed to persons who have been sentenced to imprisonment of more than two years or a sentence of strict-security prison (with forced labour) but who have not been convicted earlier (first-time offenders), or to those treated under the law as unconvicted persons, as well as to those who have been convicted of committing multiple offences. As for persons sentenced to a term of imprisonment of more than two years or to strict-security imprisonment, who have not been convicted earlier, the court, acting upon their personal request, may permit the erasure of conviction, provided that eight years have elapsed from the date the sentence was served, outdated or abolished, if the convicted person has compensated the damage according to his abilities, and if by his conduct the person deserved the erasure of conviction.

In case the person has been convicted multiple times, judicial rehabilitation may be granted when the time envisaged for each separate conviction expires. Apart from this requirement, the following conditions must be met as well: a) those pertaining to the conduct of the convicted person; b) those pertaining to the gravity and the consequences of the committed crime; and c) those pertaining to possible compensation of damage caused by a criminal offense.

Upon the request of the convicted person, the court decides in each individual case whether or not the conditions prescribed by the law were fulfilled, particularly considering the discretionary right of the court to decide on the issue of the convicted person's conduct, as well as on the gravity and the consequences of the committed offense.

\subsection{Criminal Code of the Socialist Federal Republic of Yugoslavia}

The Criminal Code of the Socialist Federal Republic of Yugoslavia (SFRY) ${ }^{4}$ also provides for rehabilitation. Article 91 of this Code provides that, after a sentence has been served, outdated or abolished, or after a sentence of juvenile prison, the convicted persons are granted all rights provided for by the constitution, laws and other regulations, and may obtain all rights, except for those which they are forbidden to exercise due to the implementation of security measures or due to ensuing legal consequences. Rehabilitation is also granted to persons who are on parole, unless their rights have been restricted by special regulations.

According to Jakovljević (1981:204), this Code provides for three forms of rehabilitation: a) legal rehabilitation; b) judicial rehabilitation; and c) clemency rehabilitation.

By interpreting Articles 91-94 of this Code, it can be noticed that judicial rehabilitation is envisaged in the following cases: 1) due to the termination of security measures prohibiting the performance of professional duties, activities or obligations, prohibiting public speaking and prohibiting the person to drive a motor vehicle if three years have elapsed since the date of imposing these measures; 2) if three years have elapsed from the date the sentence was served, outdated or abolished, the court may order that the legal consequences of the conviction pertaining to the prohibition of attaining a certain right have ceased to exist,

\footnotetext{
${ }^{4}$ Criminal Code of the Socialist Federal Republic of Yugoslavia, Official Gazette SFRY no. 44/1976.
} 
3) upon the request of the convicted person, the court can decide to erase the imprisonment sentence ranging from one up to three years from the criminal records, provided that five years have elapsed since the date of the served, abolished or outdated sentence; the offender is also obliged to fulfill additional requirements, regarding non-commission of another criminal offense, good conduct, as well as those related to the gravity and the consequences of the committed crime.

When deciding whether to grant rehabilitation, the court will take into account the conduct of the convicted person and his willingness to compensate the damage and return the illegally acquired gain. This law also provides for the right of third parties to seek compensation for damage, in a special proceeding, regardless of the rehabilitation itself.

Legal rehabilitation is envisaged in the following cases: 1) when a conviction for a judicial reprimand or release from punishment is erased, provided that the person does not commit an offense within a year from issuing the final court decision; 2) a suspended sentence is erased within one year from the expiry of the probation period if no new criminal offense has been committed during that time; 3 ) a sentence to a fine is erased after the expiry of the period of three years from the date of the served, outdated or pardoned sentence, provided no new criminal offense has been committed; and 4) a sentence of up to one year of imprisonment and a juvenile imprisonment sentence is erased within five years from the date the sentence was served, outdated or abolished, unless a new criminal offense has been committed during that time.

Judicial and legal rehabilitation are not allowed during the application of security measures. In addition, the same law explicitly provides as follows: if, during the erasure period, the person who rehabilitation refers to is sentenced to a term of imprisonment exceeding three years, the erasure will not be allowed, either of the former or of the subsequent conviction. In case of multiple convictions, all convictions may only be erased simultaneously, provided that the requirements for erasing each individual conviction have been met.

\section{REHABILITATION IN THE LEGISLATION OF THE REPUbLiC OF SERBIA}

The Criminal Code of the Republic of Serbia ${ }^{5}$ defines the general concept of rehabilitation. Article 97 of this Code allows for the erasure of conviction from criminal records and ceasure of all legal consequences, so that there is a fiction that the convicted person is regarded as an unconvicted one. The meaning of this norm is reflected in the need to allow the convicted person a full resocialization after serving the sentence. By analyzing this norm, it can be concluded that this Code enables the so-called full rehabilitation.

Serbian criminal law recognizes two types of rehabilitation. These are: a) legal rehabilitation, which occurs by virtue of law; and b) judicial rehabilitation, which is ordered by the competent court. The Serbian legislator also envisaged that rehabilitation does not affect the rights of third parties, if their rights derive from the conviction.

\subsection{Legal rehabilitation}

Under Article 98 of the Serbian Criminal Code, "legal rehabilitation may be granted only to persons who, prior to conviction in respect of relevant rehabilitation, had no prior

\footnotetext{
${ }^{5}$ Criminal Code of the Republic of Serbia, Official Gazette of the Republic of Serbia no. 88/2005, 107/2005, 72/2009, 111/2009, 121/2009, 121/2012, 104/2013, 108/2914, 94/2016 and 35/2019.
} 
convictions, or are by law considered to be without prior convictions". Legal rehabilitation is granted in the following circumstances: a) if the person who has been convicted but released from punishment, or the person who has been issued a judicial admonition, does not commit another criminal offense within a period of one year after the judgment becomes final; b) if the person who has been issued a suspended sentence does not commit another criminal offense during the probation period and within one year after the end of the probation period; c) if the person who has been sentenced to a fine, community service, revocation of a driving license, or imprisonment not exceeding six months does not commit another criminal offense within the period of three years after the date when the sentence was abolished or outdated under the statute of limitations; d) if the person who has been sentenced to imprisonment ranging from six months up to one year does not commit another criminal offense within a period of five years from the date when the sentence was served, outdated or abolished; and e) if the person who has been sentenced to a term of imprisonment ranging from one up to three years does not commit another criminal offence within a period of ten years after the sentence was served, abolished or outdated under the statute of limitations (Article 98 para. 2 CC). However, Article 98 para. 3 CC envisages that "legal rehabilitation shall not ensue if the secondary penalty has not been enforced or if security measures are still in force".

\subsection{Judicial rehabilitation}

Under Article 99 of the Serbian Criminal Code, judicial rehabilitation can be granted to a convicted person who files a request with the competent court if the following requirement have been met: a) the person was sentenced to a term of imprisonment ranging from three to five years, provided that the person does not commit another criminal offence within a period of ten years from the date the sentence was served, outdated or abolished; b) the convicted person deserved rehabilitation due to his good conduct; and c) the convicted person compensated the damage caused by the committed criminal offense, according to his financial capacity. Judicial rehabilitation may not be granted if the secondary punishment has not been served or if security measures are still in place (Article 99 para. 3 CC).

Upon making decision on the request, the court considers other circumstances that might be of importance for granting rehabilitation, such as the gravity and the legal consequences of the committed offense. Given the fact that the court decides on the merits of each case, the court has a discretionary right to decide on the specific circumstances in each case.

If the person has had multiple convictions, judicial rehabilitation can be granted only if the statutory time limit has elapsed in respect of each criminal offense that the person has been convicted for (Article $100 \mathrm{CC}$ ), and if during that time the convicted person has not committed another criminal offense time until the day the rehabilitation decision was rendered.

In case the sentence is accompanied by the prohibition, loss or termination of certain rights, after the expiry of the period of three years from the date when the sentence was served, abolished or outdated, the court may decide that the legal consequences of the conviction have ceased to exist and terminate the ban on acquiring particular rights if they have not ceased as a result of rehabilitation. In this case, the court takes into account whether the damage caused by a criminal offense has been compensated and/or whether the material gain acquired by the commission of a criminal offense has been returned (Article 101 CC). 


\section{Rehabilitation of Political Prisoners by LeX SPECialis}

\subsection{The Rehabilitation Act of 2006}

The first lex specialis on rehabilitation in the Republic of Serbia was passed half a century after the dissolution of the Informbiro in 1956 and the abolition of the political prisoners' camp on Goli Otok. On 17 April 2006, the National Assembly of the Republic of Serbia adopted the Rehabilitation $\mathrm{Act}^{6}$, which regulates the rehabilitation of persons who were deprived of life, liberty or other rights for political or ideological reasons, with or without a court or administrative decision, starting from 6 April 1941 until 25 April 2006, when this law entered into force. This law has a narrow scope, including only nine articles.

First, Article 2 of this Act stipulates that any natural or legal person has the right to submit a request for rehabilitation, which is not time-barred. Authorized persons may submit a request for rehabilitation to the competent district court (today's higher court), including personal data and evidence justifying the request. The request is made according to the place of residence or the place where the crime has been committed or prosecuted. If such a request cannot be filed by an authorized person, the Act allows the opportunity to provide the court with a description of the committed violence and/or the reasons for prosecution with information that can serve for closer identification of the victim and the event.

Article 4 of this Act stipulates that the court, before deciding on the request, should obtain all the needed documents and data from the competent state authorities and organizations, which are obliged to deliver them at the request of the court within 60 days. On this basis, in a public procedure, a panel of three judges approves or rejects the requests for rehabilitation. Although, the contribution of this law is considerable in terms of promoting the democratic awareness of the society and strengthening the responsibility of the state towards its citizens, it did not fully consider all aspects of this problem and, above all, the right of rehabilitated persons and their heirs to seek compensation.

\subsection{The Rehabilitation Act of 2011}

In view of overcoming the imperfections of the 2006 Rehabilitation Act, the National Assembly of the Republic of Serbia adopted a new Rehabilitation Act on 7 December $2011^{7}$, which is still in force. This Act regulates in more detail the subject matter of rehabilitation as well as the right of the rehabilitated persons and their heirs to compensation for damage. The enactment of this law is closely related to the previously adopted Act on Restitution of Confiscated Property and Remuneration ${ }^{8}$ since the final and effective decision on rehabilitation of the convicted person is required for restitution of property.

The 2011 Rehabilitation Act regulates rehabilitation and legal consequences of the persons who have been deprived of life, liberty and other rights for political, religious, national and ideological reasons, without a court or administrative decision. The Act applies to the territory of the Republic of Serbia, as well as outside its territory, provided that the persons have residence and citizenship of the Republic of Serbia and that they have been deprived of these rights without a court or administrative decision of military or other Yugoslav authorities. (Article 1 para.1 RA) The right to rehabilitation is also granted to

\footnotetext{
${ }^{6}$ Rehabilitation Act, Official Gazette of the Republic of Serbia no. 33/2006.

${ }^{7}$ Rehabilitation Act, Official Gazette of the Republic of Serbia no. 92/2011

${ }^{8}$ Act on Restitution of Confiscated Property and Remuneration, Official Gazette of the Republic of Serbia, no. $72 / 2011$
} 
persons who have been imposed a punishment by a court or an administrative decision which is contrary to the norms of the legal state and the generally recognized standards on human rights and freedoms (Article 1 para.2 RA). The Act stipulates that the rehabilitation procedure is actually the procedure of establishing the nullity or invalidity of the acts and actions by which the citizens have been deprived of life, liberty and other rights for political, religious, national or ideological reasons until the day of its entry into force (Article 1 para.1 RA).

The Act provides for two types of rehabilitation: a) legal rehabilitation; and b) judicial rehabilitation. The difference between them is that, in the case of legal rehabilitation, the court makes a decision declaring that the person has been rehabilitated by force of law whereas, in the case of judicial rehabilitation, the court brings a decision to rehabilitate a person. A special rehabilitation proceeding is envisaged for each type of rehabilitation. What is common to all rehabilitation proceedings is the court authority to obtain evidence on its own initiative and to conduct its own investigation on the matter at issue (Article 5 para.3 RA).

Legal rehabilitation (under the force of law) is envisaged for persons who have been deprived of liberty on the basis of a court or administrative decision, under the charges of having pleaded for the Cominform Resolution of 28 June $1948^{9}$, and the persons who have been held in political prisoners' camps or prisons on the territory of the Federal People's Republic of Yugoslavia in the period from 1949 to 1955 (Article 5 para.3 RA).

Under the 2011 Rehabilitation Act, the rehabilitation procedure is initiated by submitting a request for rehabilitation, which can be submitted by: a) the convicted person; and b) his legal heirs (spouse, children, brothers, sisters, testamentary beneficiaries), which is an important novelty in comparison to the 2006 Rehabilitation Act. In the case of particularly grave violations of the rule of law and the generally accepted standards of human rights protection, the rehabilitation procedure may also be initiated by a public prosecutor (Article $7 \mathrm{RA}$ ).

The procedure of legal rehabilitation on the basis of the Informbiro Resolution is conducted before a higher court in the territory of the claimant's place of residence or the place where the convicted person's rights were violated. The decision is taken by a single judge. Given the subject matter of this legal rehabilitation (the Informbiro Resolution), it should be noted that the court proceedings involve a single party (claimant); they are conducted under the rules of non-contentious proceedings, which entail an obligation of the court to obtain a prior opinion of the competent public prosecutor from the Higher Public Prosecution Office. If the public prosecutor does not contest the submitted request and the allegations contained in it, the process is completed as a single-party proceeding. However, if the prosecutor does contest the request, then the proceedings involve two parties, whereby the second party (respondent) is the Republic of Serbia, represented by the public prosecutor from the Higher Public Prosecution_Office. In this case, the procedure is the same as the procedure for judicial rehabilitation (Article 14 RA).

In these proceedings, the court establishes the facts independently. Article 13 of this Act regulates the duty of the competent state authorities and organizations to submit the data and evidence at their disposal to the court within 60 days. This Act also established new obligations of the archives, primarily the Archives of Serbia, which started obtaining access to the archival material from the Security and Information Agency (SIA) in 2004.

\footnotetext{
${ }^{9}$ For more on this issues, see: Modern History Sourcebook: Cominform Communiqué: Resolution of the Information Bureau Concerning the Communist Party of Yugoslavia, 28 June 1948, available at https://sourcebooks.fordham.edu/mod/1948cominform-yugo1.asp (accessed 12.12.2019)
} 
The steering committee of the Archives of Serbia issued a Rulebook on the conditions and manner on using this material in 2008 (Nenadić, 2009:5).

Pursuant to Article 4 (para. 2) of the 2006 Rehabilitation Act, the Archives of Serbia are required to deliver the requested data or documents to the district courts of the Republic of Serbia within 60 days from the receipt of the request. In addition to the district courts, applicants for rehabilitation are also obliged to provide evidence that their request is justified, which means that the Archives perform all the necessary research within the same time frame, upon the citizens' requests, with one significant difference. Namely, the Archives provide copies of the archival material belonging to the Security and Information Agency (SIA) only to the district courts, while citizens can only obtain information on whether a file is currently in the Archives of Serbia, but they still cannot access these files, nor obtain their copies (Nenadić, 2009:5).

The reason for this limitation in terms of use and access to the needed archival material, lies in the fact that there is no legislative act that regulates the procedure and the manner of using such archival materials and handling files, which would determine the circle of persons that could get an insight into a file or get a copy of it. Besides, as the material from SIA archives has still not been completely retrieved, or archived, it cannot be put to use (Nenadić, 2009: 5). In the first three years of implementation of the 2006 Restitution Act, the Archives of Serbia responded to 1,100 requests. The number of requests was significantly increased after the entry into force of the 2011 Rehabilitation Act, which provides the right to rehabilitation compensation under Article 26. In the period from 2009 to 2017, the Archives of Serbia received 16,958 requests. The reception of the material from SIA archives continued. As recorded by Petrović, "around 1,000 SIA collections have been received so far, which is close to 380,000 pages of text and 80,000 personal files (criminal records) classified into 36 categories (war criminals, Chetniks, Ustashas, members of Ljotić and Nedić nationalist groups, Informbiro supporters, and other class and ideological enemies). The volume of these personal files varies from one to several dozens, hundreds or thousands of pages; the most extensive one has 11,425 pages" (Petrović, 2017:18).

However, the largest share of the increased workload is related to the requests submitted by higher courts, especially when a single letter of request covers research on a larger number of persons. For instance, in a single letter, the Higher Court in Sombor asked for available documentation on 212 persons. Petrovic notes that research activities are complex: "In order to provide data on a single person, it is sometimes necessary sometimes to check 20, 30 or 40 personal files which are kept under the same name and surname. Once the file is ascertained to pertain to the particular person, the relevant documentation is selected and copied; anonymity of personal data of third parties is ensured by darkening the text containing data on such persons; then, the document is copied again and such a copy is sent to the competent higher courts. If the document is illegible, but of utmost importance for the procedure of rehabilitation, its transcript is made upon a request of the court "(Petrović, 2017: 18)

Judicial practice has substantiated the provisions of the Rehabilitation Act; thus, there has been no difficulty in the process of rehabilitation of people convicted on the grounds of the Informbiro Resolution. Article 17 of this Act specifies that the decision by which the court approves the request for legal and judicial rehabilitation has to establish that the prior decision made against the rehabilited person is null and void since its adoption, and that its legal consequences are null and void.

This Act also regulates the procedure for exercising the right to rehabilitation compensation. Articles 26 and 27 of this Act envisage the type of damage as well as the circle of persons who can be compensated. Thus, the rehabilitated person is entitled to 
compensation of pecuniary or non-pecuniary damage, as well as to the reimbursement of paid fines and costs of the proceedings in revaluated amounts (by calculating the current value of formerly paid amounts). Article 21 of this Act specifies that the right to rehabilitation compensation is granted to a spouse, children, parents, brothers, sisters and extramarital partners of the rehabilitated person, provided that a more permanent community of life existed between them and the deceased rehabilitated person, in line with the law regulating obligation relations. Article 23 of this Act provides for the right to a special monthly allowance to the rehabilitated person in the amount of $50 \%$ of the average monthly pay in the Republic of Serbia for the previous year. The said allowance is calculated and paid by the Republic Pension and Disability Insurance Fund.

\section{CONCLUSION}

The first part of the paper provides an overview of the historical development of the institute of rehabilitation in the legislation of the Kingdom of Serbs, Croats and Slovenes and in a number of post-war criminal codes in Yugoslavia. The second part presents the legal provisions on rehabilitation envisaged in the current Serbian criminal legislation. Taking all these provisions into account, it can be noticed that, in order to erase the conviction, it has always been necessary to fulfill several formal and substantive requirements prescribed by the law. In addition to meeting the specified time limit for erasure after the sentence has been served or abolished, it has always been necessary to consider the conduct of the convicted person in the course of serving the sentenced, as well as his willingness to compensate the damage caused by the committed criminal offense. Modern legislations have largely retained such a conception of the concept, characteristics, effects and conditions for granting rehabilitation.

Upon reviewing the legislation from 1929 until the present day, there is a notable fact that the rights of third parties have never been restricted by the application of rehabilitation; hence, third parties have always been able to exercise their rights stemming from the conviction in a separate procedure. The legislator has managed to find a compromise: on the one hand, the convicted person is held responsible for a committed criminal offense and, on the other hand, the person is given a chance to integrate into the society.

The integration of the convicted person itself is of crucial importance for each society, including the Republic of Serbia. In the long run, resocialization should play an important role in decreasing the crime rate and recidivism. However, the issue of resocialization in Serbian society is still largely uncertain. One of the reasons for this situation lies in the stigmatization of convicted offenders by society which, in addition to the imposed sentence, is an additional punishment for the convicted person.

In the Republic of Serbia, the institute of rehabilitation is prescribed in two legislative acts: 1) the Criminal Code, which differentiates between legal rehabilitation and judicial rehabilitation; and 2) special legislative act on rehabilitation enacted in 2011.

In terms of the Criminal Code provisions, rehabilitation requires the fulfillment of certain conditions pertaining to the prior conviction of the criminal offender, the specific period of time after the sentence was served, abolished or outdated during which the convicted person did not commit another criminal offense, good conduct of the convicted offender and his willingness to compensate for the damage caused by the committed offence. These conditions are prescribed by the Criminal Code, but the competent courts determine whether the requirements have been met and decide on the appropriacy of granting rehabilitation. 


\section{REFERENCES}

Babić, M., Marković, I. (2015). Krivično pravo,-Opšti deo (Criminal Law- General Part), Pravni fakultet, Banja Luka

Čubinski, M. (1934). Naučni i praktični komentar Krivičnog zakonika Kraljevine Jugoslavije (Commenary on the Criminal Code of the Kindgdom of Yugoslavia-theoretical and practical aspects), Beograd, 1934.

Jakovljević, D. (1981). Rehabilitacija u krivičnom pravu (Rehabilitation in Criminal Law), Beograd, Servis Saveza udruženja pravnika Jugoslavije.

Nenadić, M. (2017). Primena Zakona o rehabilitaciji u Arhivu Srbije (Application of the Rehabilitation Act in the Archives of Serbia), Arhivski glasnik br. 6/2017, str.5

Petrović, B. (1929). Novi krivični zakonik za kraljevinu Jugoslaviju i ideje trodeobnog (tripartitnog) sistema u nauci krivičnog prava (The new Criminal Code of the Kingdom of Yugoslavia and ideas of the tripartite system in criminal law theory), Branič, br. 1-6./1929, str. 114-118

Petrović, V. (2017). Značaj arhivske građe BIA-e u procesu rehabilitacije i restitucije (Significance of the SIA Archives in the process of rehabilitation and restitution), Arhivski glasnik broj 12/2017, str. 19-20.

\section{LEGAL DOCUMENTS}

Krivični zakonik Srba, Hrvata i Slovenaca, Službene novine Kraljevine Srba, Hrvata i Slovenaca (Criminal Code of the Kingdom of Serbs, Croats and Slovenes, 1929), Službene novine Kraljevine SHS br. 33/1929

Krivični zakonik Federativne Narodne Republike Jugoslavije - opšti deo (Criminal Code of the Federal People's Republic of Yugoslavia-General Part, 1947), Službeni list FNRJ br. 106/1947

Krivični zakonik Federativne Narodne Republike Jugoslavije (Criminal Code of the Federal People's Republic of Yugoslavia, 1951), Službeni list FNRJ br. 13/1951

Krivični zakonik Socijalističke Federativne Republike Jugoslavije (Criminal Code of the Socialist Federal Republic of Yugoslavia, 1976), Službeni list SFRJ br. 44/1976

Krivično zakonik Republike Srbije (Criminal Code of the Republic of Serbia), Službeni glasnik Republike Srbije br. 88/2005, 107/2005, 72/2009, 111/2009, 121/2009, 121/2012, 104/2013, 108/2914, 94/2016 and $35 / 2019$.

Zakon o rehabilitaciji (Rehabilitation Act), Službeni glasnik Republike Srbije br. 33/2006 (2006)

Zakon o rehabilitaciji (Rehabilitation Act), Službeni glasnik Republike Srbije br. 92/2011 (2011)

Zakon o vraćanju oduzete imovine i obeštećenju (Act on Restitution of Confiscated Property and Remuneration), Službeni glasnik Republike Srbije br. 72/2011

\section{INSTITUT REHABILITACIJE KROZ PRAVNE SPOMENIKE DOMAĆEG PRAVA 1929-2011. GODINE}

Ove godine navršava se devet decenija od donošenja Krivičnog zakonika za Kraljevinu Srva, Hrvata i Slovenaca koji je stupio na snagu 29. januara 1929. godine. Sem ujednačavanja krivičnih zakona na celoj teritoriji kraljevine, na kojoj je pre toga važilo nekoliko različitih kaznenih zakona, novi Zakonik propisao je institut rehabilitacije koju nisu poznavali stari kazneni zakoni. Novi pravni poredak, ustanovljen posle Drugog svetskog rata u novoformiranoj državi iznedrio je nove krivične zakonike uskađene sa vremenom i vrednostima koje država štiti- Krivični zakonik FNRJ iz 1947, Krivični zakonik FNRJ iz 1951, Krivični zakonik SFRJ iz 1976. godine. Svi oni sadržali su odredbe o rehabilitaciji. $U$ novije vreme ovaj institut sadržan je u važećem krivičnom zakoniku Republike Srbije i posebnim zakonima o rehabilitaciji političnih osuđenika iz 2006. i 2011. godine. Ovaj rad ima za cilj da kroz istorijsku prizmu sagleda normativno uređenje rehabilitacije u našem pravnom sistemu.

Ključne reči: rehabilitacija, krivični zakoni, resocijalizacija

Translated by: Danica Milošević

Proofreading/copyediting: Gordana Ignjatović 